\title{
EFEKTIVITAS PEMBERIAN EKSTRAK DAUN BELIMBING WULUH (Averrhoa bilimbi Linn) TERHADAP PENURUNAN LEUKOSIT PADA MENCIT INFEKSI NIFAS
}

\author{
Tut Rayani Aksohini Wijayanti ${ }^{1}$, Rani Safitri ${ }^{2}$ \\ ${ }^{1}$ tutrayani@gmail.com, ${ }^{2}$ raniandriatno@gmail.com \\ ${ }^{1,2)}$ Prodi Diploma III Kebidanan \\ Poltekkes RS dr Soepraoen Malang \\ Jl.S.Supriadi No.22, Sukun, Kota Malang, Jawa Timur 65147
}

\begin{abstract}
Postpartum infection is one of the causes of maternal death in Indonesia. Stapylococcus aureus is an invasive gram-positive bacterium and causes various infections. Widespread bacterial resistance to antibiotics, encouraged in the search for alternative steps with the provision of natural antibacterial ingredients. Flavonoids, saponins, tannins are active ingredients contained in the leaves of starfruit which can be used as antibacterial. The purpose of this study was to determine the effect of giving starfruit leaf extract (Averrhoa bilimbi Linn) to the decrease in the number of leukocytes in mice with puerperal infection. The research method used is true experiment posttest only control group design. Research replication of mice was 24 and grouped into 4 namely control, group P1 (extract of belimbing wuluh leaf dose $100 \mathrm{mg} / \mathrm{kg} / \mathrm{BB}$ ), group P2 (extract of belimbing wuluh leaf dose $200 \mathrm{mg} / \mathrm{kg} / \mathrm{BB}$ ) and group P3 (leaf extract starfruit wuluh dose of $400 \mathrm{mg} / \mathrm{kg} / \mathrm{BB}$ ). The measurement of leukocyte count was carried out using the Hematology Analyzer Sysmax KX-21. The results showed that there was a significant decrease in the number of leukocytes in the treatment group giving extracts of wuluh starfruit leaves $100 \mathrm{mg} /$ $\mathrm{kgBB}, 200 \mathrm{mg} / \mathrm{kgBB}$ and $400 \mathrm{mg} / \mathrm{kgBB}$. Provision of leaf starfruit extract has been shown to reduce leukocytes in mice with puerperal infection. Therefore the extract of starfruit leaves can be beneficial to increase the body's immunity so that no infection occurs during the puerperium.
\end{abstract}

Keyword: Staphylococcus aureus, leukocytes

\begin{abstract}
Abstrak
Infeksi nifas merupakan salah satu penyebab kematian maternal di Indonesia. Stapylococcus aureus merupakan bakteri gram positif yang bersifat invasive dan menyebabkan berbagai infeksi. Meluasnya resistensi bakteri terhadap antibiotik, mendorong dalam pencarian langkah alternatif dengan pemberian antibakteri berbahan alami. Flavonoid, saponin, tanin merupakan bahan aktif yang terkandung dalam daun belimbing wuluh yang dapat digunakan sebagai antibakteri. Tujuan penelitian ini adalah mengetahui pengaruh pemberian ekstrak daun belimbing wuluh (Averrhoa bilimbi Linn) terhadap penurunan jumlah leukosit pada mencit infeksi nifas. Metode penelitian yang digunakan adalah true experiment posttest only control group design. Replikasi penelitian mencit sebanyak 24 ekor dan dikelompokkan menjadi 4 yaitu kontrol, kelompok P1(ekstrak daun belimbing wuluh dosis $100 \mathrm{mg} / \mathrm{kg} / \mathrm{BB}$ ), kelompok P2 (ekstrak daun belimbing wuluh dosis 200 $\mathrm{mg} / \mathrm{kg} / \mathrm{BB}$ ) dan kelompok P3 (ekstrak daun belimbing wuluh dosis $400 \mathrm{mg} / \mathrm{kg} / \mathrm{BB}$ ). Pengukuran jumlah leukosit dilakukan dengan menggunakan Hematology Analyzer Sysmax KX-21. Hasil penelitian menunjukkkan bahwa terdapat penurunan jumlah leukosit yang signifikan pada kelompok perlakuan pemberian ekstrak daun belimbing wuluh $100 \mathrm{mg} / \mathrm{kgBB}, 200 \mathrm{mg} / \mathrm{kgBB}$ dan $400 \mathrm{mg} / \mathrm{kgBB}$. Pemberian ekstrak daun belimbing wuluh terbukti dapat menurunkan leukosit pada mencit infeksi nifas. Oleh karena itu ekstrak daun belimbing wuluh dapat bermanfaat untuk meningkatkan imunitas tubuh agar tidak terjadi infeksi pada masa nifas berlangsung.
\end{abstract}

Kata Kunci: Staphylococcus aureus, leukosit

\section{Pendahuluan}

Angka kematian ibu di Indonesia pada tahun 2016 sebesar 309 per 100.000 kelahiran hidup. Data AKI pada tahun 2016 ini masih sangat jauh dari target SDGs tahun 2030. Salah satu faktor 
penyebab kematian ibu di Indonesia yaitu adanya infeksi nifas dengan angka kejadian sebesar $7,3 \% .^{[1]}$ Adanya perlukaan-perlukaan kecil di daerah reproduksi terutama saat masa nifas dapat menimbulkan munculnya bakteri patogen. Strain bakteri yang paling umum diisolasi salah satunya yaitu bakteri Stapylococcus aureus. ${ }^{[2]}$ Stapylococcus aureus merupakan kelompok bakteri gram positif yang bersifat invasive dan mampu menyebabkan berbagai penyakit infeksi. ${ }^{[3]}$

Berdasarkan penelitian Nahid (2009) didapatkan data bahwa sekitar 6077 pasien yang berada di Rumah Sakit Khanevadeh dari tahun 2003 sampai dengan tahun 2008 terdapat 461 pasien yang menderita infeksi post partum, diantara infeksi tersebut salah satu penyebabnya yaitu Stapylococcus aureus. ${ }^{[4] \quad \text { Stapylococcus aureus }}$ menghasilkan alpha hemolysisn yang menjadi tanggung jawab terhadap akibat yang ditimbulkan di inangnya.

Antibiotik biasanya digunakan sebagai pengobatan terhadap infeksi namun sering kali hasilnya tidak memuaskan.Hal ini dipengaruhi oleh ketidakteraturan dalam menggunakan antibiotik sehingga mengakibatkan mikroba mutan. Hal ini mengakibatkan bakteri resisten terhadap berbagai antibiotic. ${ }^{[5]}$ Meluasnya resistensi bakteri terhadap antibiotik yang ada, mendorong dalam pencarian langkah alternatif dengan pemberian antibakteri berbahan alami.

Negara Indonesia dikenal kaya akan bahan alam sehingga banyak masyarakat yang telah menggunakannya sebagai obat tradisional. Namun dalam penggunaannya harus diketahui terlebih dahulu potensi dari tanaman tersebut. Dalam penelitian yang dilakukan oleh Zakaria et al. (2007) didapatkan data bahwa pertumbuhan bakteri Stapylococcus aureus dapat dihambat dengan menggunakan air belimbing wuluh konsentrasi $2 \mathrm{mg} /$ disk. $^{[6]}$

Belimbing wuluh (Averrhoa bilimbi Linn) merupakan tanaman liar yang sering tumbuh di kebun, ladang maupun pekarangan rumah. Masyarakat sering memanfaatkan tanaman ini sebagai obat rematik, stroke, batuk dan anti radang. ${ }^{[7]}$ Flavonoid, saponin, tanin, asam format, kalsium oksalat, kalium sitrat, sulfur dan peroksidase merupakan bahan aktif yang terkandung dalam daun belimbing wuluh. ${ }^{[8]}$

Ummah (2010) dalam penelitiannya membuktikan bahwa kandungan saponin, flavonoid dan tanin dalam daun belimbing wuluh memiliki efek antibakteri terhadap Staphylococcus aureus. ${ }^{[9]}$ Berdasarkan penelitian sebelumnya, maka perlu dilakukan pengujian "Efektifitas pemberian ekstrak daun belimbing wuluh (Averrhoa bilimbi Linn) terhadap penurunan leukosit pada mencit infeksi nifas". Tujuan penelitian ini adalah mengetahui pengaruh pemberian ekstrak daun belimbing wuluh (Averrhoa bilimbi Linn) terhadap penurunan jumlah leukosit pada mencit infeksi nifas.

\section{Metode penelitian}

Penelitian ini merupakan penelitian true Eksperimental dengan rancangan prepost test randomized control group design. Variabel bebas dalam penelitian ini adalah pemberian ekstrak daun belimbing wuluh (Averrhoa bilimbi Linn) dan variabel terikatnya jumlah leukosit. Penelitian dilakukan di laboratorium Parasitologi Fakultas Kedokteran Universitas Brawijaya.

Sampel dari penelitian ini adalah mencit (Mus musculus) betina bunting usia kehamilan 14 hari dengan berat badan 45 gram. Mencit dibagi dalam 4 kelompok berdasarkan simple random sampling yaitu kelompok 1 (kontrol positif diinfeksi Staphyloccus aureus tanpa perlakuan), kelompok 2 (diinfeksi Staphyloccus aureus +diberi ekstrak 
daun belimbing wuluh $100 \mathrm{mg} / \mathrm{kgBB}$, kelompok 3 (diinfeksi Staphyloccus aureus + diberi ekstrak daun belimbing wuluh $200 \mathrm{mg} / \mathrm{kgBB}$ dan kelompok 4 (diinfeksi Staphyloccus aureus + diberi ekstrak daun belimbing wuluh $400 \mathrm{mg} / \mathrm{kgBB}$.

Status imunologi dalam penelitian ini diukur dengan parameter jumlah leukosit yang diperiksa dengan menggunakan Hematology Analyzer Sysmax KX-21.

Staphyloccus aureus yang digunakan adalah isolat dengan nomor $100-\mathrm{SV}$ yang diberikan secara intravaginal dengan spuit $1 \mathrm{cc}$ (menggunakan jarum plastik) satu kali pada $0 \mathrm{~s} / \mathrm{d} 12$ jam post partum atau segera setelah melahirkan dengan dosis $5 \times 10^{7}$ sebanyak $200 \mu \mathrm{l}$ mencit supaya terjadi infeksi nifas. Staphyloccus aureus berasal dari Laboratorium Mikrobiologi Fakultas Kedokteran Universitas Bawijaya Malang.

Sampel berupa darah yang diambil dari pembuluh darah retroorbital mencit dengan menggunakan kapiler hematokrit.Pelaksanaan penelitian yaitu kelompok P1-P4 diberi pakan standar Pada hari ke-2 masa nifas semua mencit Balb/C diambil darahnya untuk pemeriksaan jumlah leukosit.

Data yang didapat diolah menggunakan computer dan dianalisis dengan One Way ANOVA.Apabila terdapat perbedaan dilanjutkan dengan Uji Beda Nyata Terkecil (BNT).

\section{Hasil dan pembahasan}

Keseluruhan sampel memenuhi syarat penelitian. Total sampel berjumlah 24 ekor mencit. Berdasarkan penelitian didapatkan hasil efektivitas ekstrak daun belimbing wuluh (Averrhoa bilimbi Linn) terhadap penurunan leukosit pada mencit infeksi nifas.Jumlah leukosit dapat dilihat pada tabel berikut ini.
Tabel 1 Karakteristik Mencit Infeksi Nifas Berdasarkan Jumlah Leukosit $\left(10^{3} / \mu \mathrm{l}\right)$

\begin{tabular}{ccccc}
\hline \multirow{2}{*}{ Sampel } & \multicolumn{4}{c}{ Kelompok } \\
\cline { 2 - 5 } & Kontrol & P1 & P2 & P3 \\
\hline 1 & 14,40 & 9,35 & 8,80 & 6,10 \\
2 & 16,40 & 10,80 & 5,80 & 7,55 \\
3 & 11,10 & 10,40 & 5,45 & 5,95 \\
4 & 12,45 & 10,40 & 10,05 & 7,80 \\
5 & 11,85 & 10,75 & 6,20 & 6,20 \\
6 & 13,85 & 10,55 & 10,20 & 8,80 \\
Rata-rata = sd & $13,45 \pm 1,94$ & $10,38 \pm 0,53$ & $7,75 \pm 2,19$ & $7,07 \pm 1,16$ \\
\hline
\end{tabular}

Pada tabel 1 didapatkan kelompok

kontrol yang diberi injeksi Staphyloccus aureus pada $0 \mathrm{~s} / \mathrm{d} 12$ postpartum atau segera setelah melahirkan dengan dosis dosis $5 \times 10^{7} \mathrm{CFU} / \mu \mathrm{l}$ secara intravaginal dan kelompok perlakuan yang akan diberi perlakuan setelah 2 jam injeksi Staphyloccus aureus, kemudian setelah 24 jam pemberian injeksi Staphyloccus aureus dan ekstrak daun belimbing wuluh (Averrhoa bilimbi Linn) dilakukan pengambilan darah melalui vena orbital untuk dilakukan pemeriksaan darah lengkap.

Tabel 2 Pengujian Efektivitas Ekstrak Daun Belimbing Wuluh (Averrhoa bilimbi Linn) terhadap Penurunan Leukosit Pada Mencit Infeksi Nifas

\begin{tabular}{ccc}
\hline Perlakuan & Mean \pm SD & p-value \\
\hline $\mathrm{K}+$ & $13,45 \pm$ & \\
& 1,94 & \\
P1 & $10,38 \pm$ & \\
& 0,53 & 0,007 \\
P2 & $7,75 \pm 2,19$ & \\
P3 & $7,07 \pm 1,16$ & \\
\hline
\end{tabular}

Pada tabel 2 berdasarkan uji perbandingan berganda (multiple comparison) dengan menggunakan uji IRi-RjI 5\% pada perbandingan kelompok kontrol dan kelompok perlakuan didapatkan p-value 0,007 $(\mathrm{p}<0,05)$ pada kelompok 100, 200, 400 $\mathrm{mg} / \mathrm{kgBB}$. Hal ini menunjukkan bahwa terdapat penurunan jumlah leukosit yang 
signifikan pada kelompok perlakuan pemberian ekstrak daun belimbing wuluh $100 \mathrm{mg} / \mathrm{kgBB}, 200 \mathrm{mg} / \mathrm{kgBB}$ dan $400 \mathrm{mg} / \mathrm{kgBB}$. Hal ini ditunjukkan dari kelompok perlakuan dosis 100, 200 dan $400 \mathrm{mg} / \mathrm{kgBB}$, rata-rata jumlah leukosit tidak berbeda signifikan secara statistik dengan kelompok kontrol, meskipun secara deskriptif terjadi penurunan ratarata jumlah leukosit pada semua kelompok perlakuan.

Hasil penelitian menunjukkan bahwa dengan pemberian ekstrak daun belimbing wuluh (Averrhoa bilimbi Linn) dapat memiliki efektivitas dalam menurunkan jumlah leukosit pada mencit infeksi nifas. Hal ini dipengaruhi oleh kandungan ekstrak daun belimbing wuluh (Averrhoa bilimbi Linn) yaitu flavonoid, saponin dan tannin. Flavonoid ini merupakan golongan terbesar dari senyawa fenol yang mempunyai sifat efektif menghambat pertumbuhan virus, bakteri dan jamur. Flavonoid juga dapat menyebabkan terjadinya kerusakan permeabilitas dinding sel bakteri. Selain itu, flavonoid juga mampu menghambat motilitas bakteri. Terdapat tiga mekanisme kerja flavonoid sebagai antibakteri menurut Cushine and Lamb (2005), yaitu mencegah sintesis asam nukleat, mencegah berfungsinya membran sitroplasma dan mencegah terjadinya metabolisme energi. ${ }^{[0]}$ Flavonoid berfungsi sebagai antibakteri dengan cara membentuk senyawa kompleks terhadap protein ekstraseluler yang menggangu integritas membran sel bakteri. Selain itu flavonoid juga dapat meningkatkan kemampuan imuno stimulan dari sel-sel radang, termasuk makrofag sehingga aktivasi makrofag akan lebih cepat. Roy (2011) dalam penelitiannya mengungkapkan bahwa dalam ekstrak daun Averrhoa bilimbi Linn terdapat kandungan kimia bioaktif berdasarkan analisis fitokimia metanol dan etanol yaitu flavonoid, saponin, tanin, sulfur, asam format, peroksidase, kalsium oksalat, dan kalium sitrat yang dapat digunakan sebagai anti bakteri. ${ }^{[11]}$ Gunawan (2009) disebutkan bahwa flavonoid dapat menghambat fungsi DNA bakteri sehingga akan terjadi hambatan pada proses replikasi dan translasi bakteri. $^{[12]}$ Penghambatan terhadap proses tersebut dilakukan dengan merusak membrane sitoplasma bakteri yang terdiri atas lipid dan asam amino dengan mengeluarkan gugus alcohol pada senyawa flavonoid. Proses ini akan menyebabkan dinding sel rusak sehingga senyawa tersebut dapat masuk kedalam inti sel bakteri. Selanjutnya senyawa tersebut kontak dengan DNA pada inti sel bakteri. Perbedaan kepolaran antara lipid penyusun DNA dengan gugus alkohol pada senyawa flavonoid tersebut akan menyebabkan rusaknya struktur lipid dari DNA bakteri sehingga bakteri akan mengalami lisis dan mati.

Staphyloccus aureus merupakan bakteri gram positif yang memiliki susunan peptidoglycan pada dinding selnya dan Lipopolysacharida (LPS) dapat memicu aktivasi komplemen pada jalur alternatif. Selain itu bakteri ini juga mengekspresikan ikatan mannosebinding lectin yang dapat mengaktifkan jalur lectin komplemen. Salah satu fungsi dari aktivasi komplemen pada respon imun adalah opsonisasi yang meningkatkan fagositosis ${ }^{13}$. Saponin merupakan senyawa yang bersifat antibakteri dengan merusak membran sel bakteri. Membran sel bakteri berfungsi sebagai jalan keluar masuknya bahan-bahan penting yang dibutuhkan bakteri. Apabila membran sel mengalami kerusakan akan mengakibatkan sel bakteri tersebut mati ${ }^{14}$. Flavonoid bekerja dengan cara denaturasi protein yang menyebabkan gangguan dalam pembentukan sel sehingga merubah komposisi komponen protein. Fungsi membran sel yang terganggu dapat menyebabkan peningkatan permeabilitas sel, diikuti 
dengan terjadinya kerusakan dan kematian sel bakteri. Adanya flavonoid akan menjaga pertumbuhan dan pertahanan terhadap pengaruh infeksi dan kerusakan dari sel bakteri ${ }^{15}$. Hal ini mengakibatkan fosfolipid tidak mampu mempertahankan bentuk membrane sel, akibatnya membrane akan bocor dan bakteri akan mengalami hambatan pertumbuhan bahkan kematian.

\section{Kesimpulan}

Berdasarkan pada uraian hasil penelitian dan analisis data yang telah dilakukan maka dapat ditarik kesimpulan bahwa pemberian ekstrak daun belimbing wuluh (Averrhoa bilimbi Linn) terbukti dapat menurunkan leukosit pada mencit infeksi nifas. Oleh karena itu ekstrak daun belimbing wuluh dapat bermanfaat untuk meningkatkan imunitas tubuh agar tidak terjadi infeksi pada masa nifas berlangsung.

\section{Ucapan terima kasih}

Dengan terselesainya penelitian ini, maka penulis mengucapkan terima kasih kepada Kemenristekdikti, BPPM/SPK/05/11/2018 atas dana hibah. Dan Letkol Ckm Arief Effendi, S. Kep. Ners, SH, MM selaku direktur Poltekkes RS dr. Soepraoen.

\section{Daftar pustaka}

[1] Kementerian Kesehatan RI. Pusat Data dan Informasi Kementerian Kesehatan RI Mother's day. 2017. [Online] Available at www.depkes.go.id

[2] Saleha, S. Asuhan Kebidanan Pada Masa Nifas. Salemba Medika: Jakarta. 2009

[3] Susanti, R,. Margareta, R. Aktivitas Fagositosis Neutrofil Terhadap Staphylococcus aureus Isolat Sapi di Jawa Tengah dengan Teknik Acridine Orange Fluorescence. Berk.Penel. Hayati; 2003:61-66.

[4] Nahid, A., Agdas, S., Farhad, H. Bacteria Isolated from Postpartum
Infections. Health Journal, Journal of Family and Reproductive. 2009

[5] Popescu, F. Microbiological Study of Antepartum and Postpartum Vaginal Flora. Abstracts. University of Medicine and Pharmacy of Craiova. 2013

[6] Zakaria, Z. A., Zaiton, H., Henie, E. F. P., Mat Jais, M. A, In vitro Antibacterial Activity of Averrhoa bilimbiL. Leaves and Fruits Extracts. International Journal of Tropical Medicine. 2007: 2 (3), 96100.

[7] Pendit, P, Zubaidah, E, Sriherfyna, FH. Karakteristik Fisik-Kimia dan Aktifitas Antibakteri Ekstrak Daun Belimbing Wuluh (Averrhoa bilimbi Linn). J. Pangan dan Agroindustri. 2016. Vol 4 No 1 p. 400-409.

[8] Faharani, G. Uji Aktivitas Antibakteri Daun Belimbing Wuluh terhadap Bakteri Streptococcus aureus dan Escherichia coli secara Bioautografi. Fakultas Matematika dan IPA. Jakarta: Universitas Indonesia. 2008

[9] Ummah,M.K. Ekstraksi dan pengujian aktivitas antibakteri senyawa tannin pada daun belimbing wuluh (Averrhoa belimbi L.) kajian variasi pelarut. Skripsi. Malang: UIN Malang. 2010

[10] Cushnie, T. P, Lamb, A. J. Antimicrobial activity of flavonoids. International Journal of Antimicrobial Agents. 2005. 26, 343-356.

[11] Roy, A., Geetha, Lakshmi. Averrhoa bilimbi linn-nature's drug store-a pharmacological review. International Journal of Drug Development \& Research. 2011; 3(3):101-106.

[12] Gunawan,A.W.I. Potensi Buah Pare (Momordi cacharantia L.) Sebagai Antibakteri Salmonella typhimuriumll.Tidak Diterbitkan. Skripsi. 2009 
[13] Abbas A.K,et al. Cellular and molecular immunology7thed.text book. 2012

[14] Ajizah, A. Sensitivitas Salmonella Typhymurium terhadap Ekstrak Daun Jambu Biji (Psidium guava L.). Bioscientiae. 2004; 1(1).

[15] Redha A. Flavonoid : struktur, sifat antioksidatif dan peranannya dalam sistem biologis. Jurnal Berlian. 2010; 9(2):196-202. 